\title{
Ronald Leslie Bell: 12th September 1929-25th December 2017
}

\author{
William Bonfield ${ }^{1}$, Terence G. Langdon ${ }^{2}$, and Arthur F. W. Willoughby ${ }^{2, *}$ \\ ${ }^{1}$ Department of Materials Science and Metallurgy, University of Cambridge, 27 Charles Babbage Rd, Cambridge CB3 OFS, UK \\ ${ }^{2}$ Materials Research Group, Faculty of Engineering and the Environment, University of Southampton, Southampton SO17 1BJ, UK
}

\author{
Received: 4 March 2018 \\ Published online: \\ 12 March 2018 \\ (C) The Author(s) 2018. This \\ article is an open access \\ publication
}

It is with sadness that we announce the passing of one of the founder members of the Editorial Board of this journal, Ronald Leslie Bell (Fig. 1). As his Ph.D. students and colleagues, we felt it was important to record this obituary in the Journal to which he gave so much. It is not always recognised that the Journal of Materials Science, founded in 1966, was one of the first initiatives in the recognition and identity of the Materials Science discipline worldwide, from its roots in metallurgy and more specialised materials subjects. In this discipline, Ron Bell played an important part, as a member of an Editorial Board covering the wide range of materials that we know today. The first Chairman of the Editorial Board was Robert Cahn, Ron's Ph.D. supervisor at Birmingham University. The other members of the Board, all from the UK, and their fields of expertise, were Ron, for metals and semiconductors, Freddy Clarke (Harwell) for ceramics, Andrew Keller (Bristol University) for polymers,

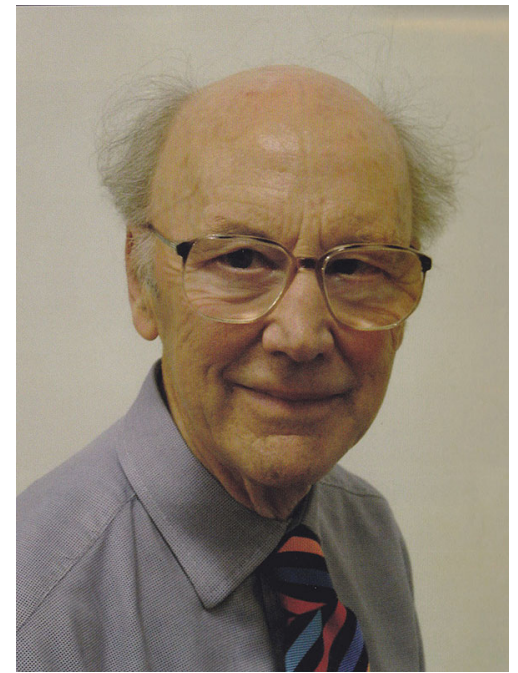

Figure 1 Ron Bell in 2007-2012.

Peter McMillan (English Electric) for glass and glass ceramics, and Geoffrey Sims (Southampton University) for electronic engineering. 
In the first issue of this journal in February 1966, Ron co-authored a paper with two of his Ph.D. students [1], and this issue also contained a letter from another of his Ph.D. students [2]. In the third issue of the journal in August 1966, Ron's joint paper [3] warranted the publication of a micrograph on the front cover, a rare honour in those days.

The growth of this journal prompted the appointment of another of Ron's former Ph.D. students, Bill Bonfield, as Executive Editor, in 1973, announced by Robert Cahn [4]. Subsequently another of Ron's former Ph.D. students, Arthur Willoughby, went on to be the founding Editor of a spin-off journal, Journal of Materials Science: Materials in Electronics, in 1990, from which he has just retired after 27 years as editor. Bill Bonfield also founded the other spin-off journal, Journal of Materials Science: Materials in Medicine. In 2006, Ron looked back on 40 years of the main journal in a joint Preface co-authored with M Grant Norton [5].

Born in 1929 in Lincoln (UK) to a family of two boys and three girls, Ron attended the Monks Road Primary Council School in 1934. Only one member of the staff had a car! He learnt art and music, and one of his paintings was selected for an exhibition in London, although he was unable to see it there. He also remembers the use of the cane in those days. He sang in the church choir at All Saints Parish church from the age of 7 .

In 1940, a year after the Second World War began, Ron moved to the City Grammar school at the age of 11 , having passed the $11+$ examination. Ron passed the school certificate and was the only one of 90 pupils to pass the Higher School Certificate a year early-partly because of the loss of younger teachers to the armed forces.

In 1947 Ron acquired an interest in metallurgy from one of his teachers, and applied for a scholarship offered by Birmingham University's metallurgy department. He was offered a place and received a City of Lincoln Major scholarship which provided $£ 140$ a year on which he comments 'was not much even in those days'. He also was awarded the metallurgy scholarship valued at $£ 210$ per year. He still managed to save some money!!

At Birmingham University, Ron joined a department which was rapidly rising in reputation to be among the best in the world. The staff included legendary names such as Alan Cottrell, Geoffrey Raynor, Bruce Bilby, Robert Cahn, Tony Kelly and
Frank Nabarro, to name but a few. Birmingham saw Ron complete his first degree and Ph.D. under the supervision of Robert Cahn, although he records little on the details of these degrees. Ron was a member of the Student Christian Movement, and, via these contacts, he met his wife Joy. After a romance of 18 months, they were married in 1954, just before he completed his Ph.D. thesis. Having succeeded to be appointed at the Royal Radar Establishment (RRE), Malvern, he was reluctantly given an extra week to finish his thesis. He records that this needed only an extra day, but he needed the rest of the week to recover from near-exhaustion!

Ron joined RRE in 1954 as a Junior Research Fellow, which had a 3-year term, but allowed freedom to pursue his own line. He was in the Transistor Physics Division headed by Alan Gibson and following up the major discoveries in junction transistors needed by the Electronics Division. His immediate boss was Bill Bardsley, and this involved the science and art of growing single crystals of silicon and germanium. Nearing the end of his three-year term, Ron looked for opportunities in Universities and was appointed to a lectureship at Imperial College, under the newly appointed Professor Geoffrey Ball. He recalls that the department, in the midst of changes, still included a senior traditional staff member who had no time for dislocations!! Research students he recalls included Bill Bonfield, Noel Thompson, Ray Latkowski, Roy Farrar, Arthur Willoughby, Paul Turner and Terry Langdon. His time at RRE proved valuable in helping him develop research projects geared to electronic materials, and his research also involved studies of creep and grain boundary sliding.

In 1965, Ron was appointed to be the first Professor of Engineering Materials at Southampton University, to which he moved. Two research students, Chris Graeme-Barber and Jeremy Birbeck, moved with him, having completed only part of their research at Imperial. Also Roy Farrar and Arthur Willoughby moved there as staff members. By coincidence, long after Ron left Southampton, Terry Langdon moved there as an Emeritus Professor from USC, California. Research students he supervised there included Ben Dobson, Peter Gadd and Levi Bueno, and his own research focussed mainly on creep at this stage. Ron's personal abilities, however, were quickly recognised by senior colleagues, and he rapidly became Dean of Engineering and then Deputy Vice Chancellor. After completing his term as DVC, he had done 20 years in 
university teaching and research and felt a change would be a good thing. He then made a step change in discipline and in his career, by becoming Director of the National Institute of Agricultural Engineering in Silsoe from 1976.

To bridge his lack of knowledge of the agricultural, horticultural and machinery industries which the NIAE at Silsoe served, Ron dedicated the special sabbatical leave which he had earned as DVC to a programme of visits around the country. In addition to farms and factories, he took in some of the other research institutes affiliated to the Agricultural Research Council. This all proved invaluable not least because NIAE, itself a member of the group, had close links and joint work with some of them. Ron writes: 'Agricultural Engineering like many other fields of industrial activity has widened its scope through the years and now embraces a large range of equipment used in animal and plant husbandry. Research into its various branches requires a range of disciplines. For instance when I joined NIAE I found a staff with degrees and/or experience in mechanical, civil and electronic engineering, physics, mathematics and agriculture (plant and animal husbandry)'.

Ron's effectiveness as director of NIAE is well summarised in the following words from one of his Heads of Division: 'You may be aware that Ron appointed me to be a Head of Division at Silsoe Research Institute-then the NIAE-back in 1983. He was a superb director, and I have many memories. Reputedly when he was first appointed as Director of Silsoe following a rather repressive regime a member of staff told him that all he had to do was take off the brakes. "Never mind the brakes", he replied, "where's the accelerator?" He brought sound research science into the engineering, coupled with a rigorous system of review and assessment. He helped me, coming from a pure science background, to understand and admire the creativity of much of the engineering research that was being done'.

After enjoying seven and a half years at Silsoe, Ron was invited to consider the post of Director General of ADAS, the Agricultural Development and Advisory Service, an operational arm of the Ministry of Agriculture, Fisheries and Food (MAFF). He was familiar with certain aspects of the job because at Silsoe there were very strong links with ADAS, but his task involved the challenge to move a typical civil service operation funded entirely from the public purse towards one that was self-funding through its earnings. His reporting structure was also to be very different. At NIAE he was virtually his own boss with responsibilities to a Governing Body and to the sponsors. At MAFF, he reported to the Permanent Secretary and thence direct to Ministers of the government. In this last job before retirement, it is clear that Ron faced many new challenges, not least the emergence of the BSE (bovine spongiform encephalopathy) crisis, and its threat of transmission to humans.

Ron retired in 1989, and, as expected, he occupied his time fully! He was one of two treasurers at the headquarters of the Methodist Church in London, which involved a lot of travel. He also enjoyed landscape and portrait painting, and making music, latterly playing the bassoon with his wife Joy playing the clarinet. Sadly Ron lost his daughter Jane in 1999 and his wife Joy in 2016. He is survived by his son Michael and daughter Ruth, and grandchildren Ann, Eleanor and Alice. We are greatly indebted to Michael for his assistance with this obituary, and for his allowing us to see Ron's autobiography, from which we have quoted some of his recollections.

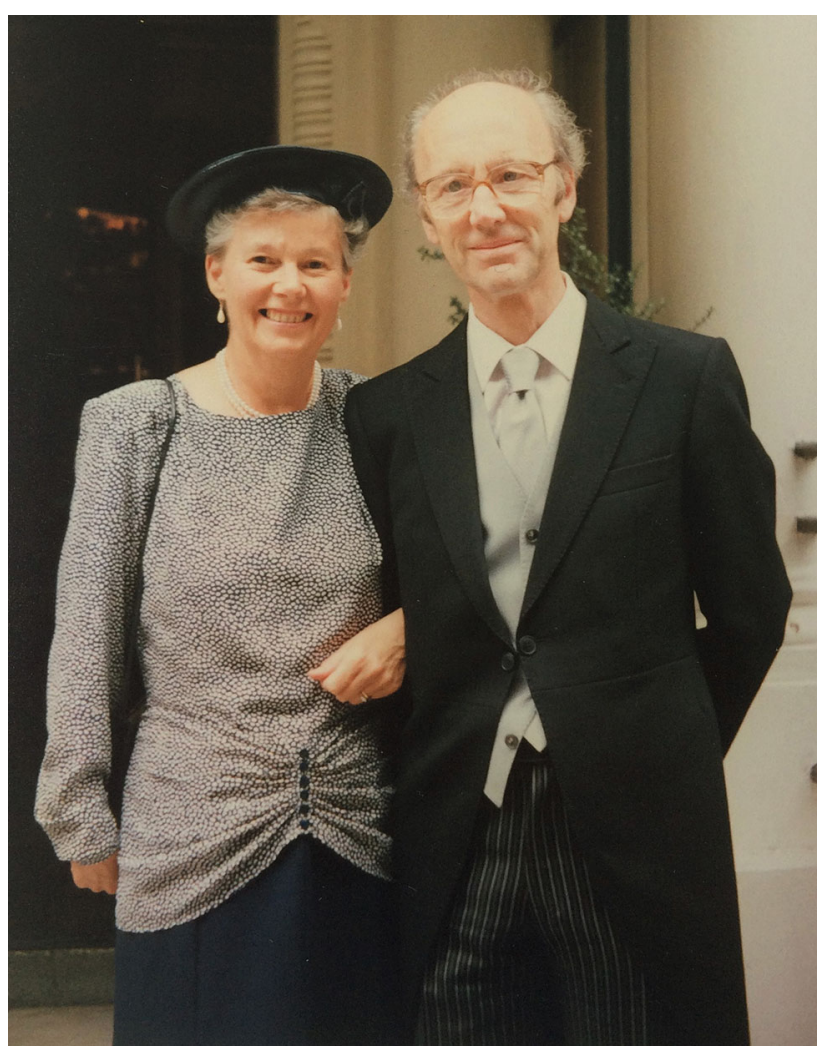

Figure 2 Ron and Joy Bell at Buckingham Palace for the CB Award 1988. 
Ron's exceptional service to the Ministry of Agriculture was recognised by his appointment to the civilian honour of Companion of Bath (CB) in 1988 (Fig. 2), while his distinctive lifetime contribution to Materials Science and Engineering received deserved recognition through his election as a Fellow of the Royal Academy of Engineering in 1991.

To summarise, Ron Bell showed extraordinary qualities in his various roles in science and engineering research and administration. To cover the wide variety of demands in these significant responsibilities is something that few could undertake successfully. As Ron's research students, we pay tribute to his guidance and inspiration in our careers, and we believe that he played a very significant part in the formation of the field of Materials Science.

\section{Open Access}

This article is distributed under the terms of the Creative Commons Attribution 4.0 International License (http://creativecommons.org/licenses/by/ $4.0 /$ ), which permits unrestricted use, distribution, and reproduction in any medium, provided you give appropriate credit to the original author(s) and the source, provide a link to the Creative Commons license, and indicate if changes were made.

\section{References}

[1] Bell RL, Latkowski R, Willoughby AFW (1966) The effect of plastic bending on the electrical properties of indium antimonide; Part 1 an initial experimental survey. J Mater Sci 1:66-78. https://doi.org/10.1007/BF00549721

[2] Turner PA, Pascoe RT, Newey CWA (1966) Grain boundary "pest" in the intermetallic compound NiAl. J Mater Sci 1:113-115. https://doi.org/10.1007/BF00549726

[3] Bell RL, Willoughby AFW (1966) Etch-pit studies of dislocations in indium antimonide. J Mater Sci 1:219-228. https://doi.org/10.1007/BF00550170

[4] Cahn RW (1973) An editorial announcement. J Mater Sci 8:459. https://doi.org/10.1007/BF00550447

[5] Norton MG, Bell RL (2006) Preface: 40 years of Journal of Materials Science. J Mater Sci 41:589-591. https://doi.org/10. 1007/s10853-006-6469-z 